Kampus 4 Universitas Ahmad Dahlan Jl. Ringroad Selatan, Tamanan, Banguntapan, Bantul

Daerah Istimewa Yogyakarta 55191

Telp. : (0274) 563515 Fax. : (0274) 564604

e-mail : ihtifaz@uad.ac.id

Vol.1, No 1\&2, Juni-Desember 2018, pp. 89-98

ISSN p:2622-4755 e:2622-4798.

DOI: https://doi.org/10.12928/ijiefb.v1i1.285

\title{
Analisis Pengaruh CAR, NPF, FDR dan Inflasi terhadap Profitabilitas Perbankan Syariah di Indonesia
}

\section{Misbahul Munir ${ }^{1 *}$}

${ }^{1}$ Magister Ekonomi dan Keuangan, Universitas Islam Indonesia, Sleman, Indonesia

*e-mail: misbahul.munir@students.uii.ac.id 


\section{Analisis Pengaruh CAR, NPF, FDR dan Inflasi terhadap Profitabilitas Perbankan Syariah di Indonesia}

\author{
Misbahul Munir ${ }^{1 *}$ \\ ${ }^{1}$ Magister Ekonomi dan Keuangan, Universitas Islam Indonesia, \\ Sleman, Indonesia \\ *e-mail: misbahul.munir@students.uii.ac.id
}

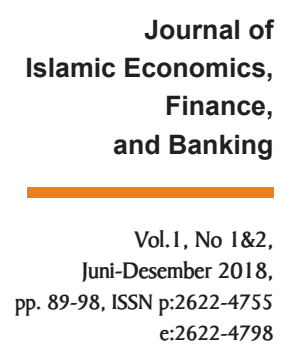

\section{Abstract}

The increasing number of sharia financial institutions in Indonesia is accompanied by an increase in literature review regarding sharia financial institutions. Renewal of studies related to the development of Islamic finance in Indonesia is important to continue. This study aims to examine the factors that affect the level of proftability of Islamic banking in Indonesia in the latest conditions and the latest data. The approach used is quantitative descriptive. Based on the $F$ test, the $f$-statistic value obtained was 0.000085 below 0.05 (five percent). In other words, the independent variables including CAR, NPF, $F D R$, and inflation simultaneously have a significant effect on the dependent variable ROA. Whereas in a formal manner, based on the $t$-test, the NPF variable has a positive and significant effect on ROA. While the CAR, FDR and inflation variables have no effect on $R O A$.

\section{Keywords:}

$C A R, N P F, F D R$, inflation, ROA

\begin{abstract}
Abstrak
Meningkatnya jumlah lembaga keuangan syariah di Indonesia dibarengi dengan meningkatnya kajian literatur terkait lembaga keuangan syariah. Pembaruan kajian terkait perkembangan keuangan syariah di Indonesia penting untuk terus dilakukan. Penelitian ini bertujuan untuk menguji faktor-faktor yang mempengaruhi tingkat profitabilitas perbankan syariah di Indonesia dalam kondisi mutakhir dan data terbaru. Pendekatan yang digunakan adalah kuantitatif deskriptif. Berdasarkan uji $\mathrm{F}$, diperoleh nilai f-statistik sebesar 0.000085 di bawah 0,05 (lima persen). Dengan kata lain, variabel independen meliputi CAR, NPF, FDR dan inflasi secara simultan berpengaruh signifikan
\end{abstract}


terhadap variabel dependen ROA. Sedangkan secara persial, berdasarkan uji $t$, variabel NPF berpengaruh positif dan signifikan terhadap ROA. Sementara IHTIFAZ - JIEFB variabel CAR, FDR dan inflasi tidak berpengaruh terhadap ROA.

\section{Kata Kunci:}

CAR, NPF, FDR, inflasi, ROA

\section{PENDAHULUAN}

Sistem kuangan syariah terus mengalami perkembangan yang cukup menggembirakan di Indonesia (Statistik Perbankan Syariah-OJK, 2018). Hal ini ditandai dengan semakin berkembangnya pertumbuhan industri bisnis dilingkungan keuangan syariah. Bahkan syariah telah menjadi bisnis baru yang tidak hanya berkutat di sektor keuangan semata. Lebih dari itu, sistem bisnis syariah sudah merambah pada berbagai sektor sektor seperti pakaian, busana, pariwisata dan kuliner (makanan).

Segala sesuatu yang bisa di bisniskan akan ditambah dengan lebel syariah jika memungkinkan. Seolah label syariah kini menjadi daya tarik tersendiri dengan segmentasi pasar yang cukup menjanjikan di Indonesia. Terlebih, Indonesia sebagai negara dengan jumlah penduduk muslim terbesar di dunia (Sari, Bahari dan Hamat: 2013). Tentu ini menjadi peluang yang cukup menjanjikan bagi semua pihak yang berkepentingan dalam pengembangan bisnis berbasis syariah.

Dari banyaknya varian bisnis yang berkembang dalam lingkup syariah, perbankan syariah masih menjadi bahasan yang dominan dalam perkembangan bisnis syariah di Indonesia. Hal ini terbukti dari banyaknya karya tulis ilmiah yang membahas perbankan syariah dibandingkan dengan tema lain di luar perbankan. Memang, sektor perbankan yang menjadi pionir sejak awal pengembangan industri syariah di Indonesia. Bank syariah pertama yang berdiri di Indonesia adalah Bank Muamalat Indonesia (BMI) pada tahun 1992 (Laporan Tahunan BMI, 2016). Berdirinya BMI ini yang kemudian menjadi tonggak berkembangnya industri perbankan syariah dan disusul oleh perkembangan bisnis syariah di berbagai sektor.

Telah banyak penelitian yang membahas seputar perkembangan perbankan syariah di Indonesia. Sebagaimana yang dilakukan oleh Syachfuddin dan Rosidi (2017) membahas tentang pengaruh variabel makro ekonomi, dana pihak ketiga dan pangsa pasar terhadap profitabilitas industri perbankan syariah di Indonesia periode tahun 2011 sampai 2015. Beberapa penelitian lain yang membahas seputar perbankan syariah, terutama dalam hal tingkat profitabilitasnya adalah Ariyani (2010); Ananda (2012); Khasanah (2017); Sumarlin (2016); Perdanasari (2017); Diknawati (2014); Welta dan Lemiyana (2017); dan Widyaningrum dan Septiarini (2015).

Dalam beberapa penelitian terdahulu sebagaimana yang telah disebutkan di atas, pada umumnya pembahasan yang dilakukan 
dalam konteks perbankan syariah dalam waktu yang lampau. Jika ada penelitian yang terbit pada tahun 2017 misalnya, pada umumnya data yang digunakan dalam penelitian adalah data tahun sebelumnya yaitu data tahun 2016 dan bahkan lebih dari itu. Sehingga perlu adanya penelitian terbaru terkait perbankan syariah dengan data dan konteks yang lebih mutakhir atau terkini. Di sinilah urgensi dari penelitian ini sekaligus menjadi alasan mengapa penelitian ini penting dilakukan.

Penelitian ini bertujuan untuk menganalisis pengaruh Capital Adequacy Ratio (CAR), Non Performing Financing (NPF), Financing to Deposit Ratio (FDR) dan inflasi terhadap profitabilitas industri perbankan syariah di Indonesia periode Juli 2015 sampai Agustus 2018. Novelty atau kebaruan dari penelitian ini adalah; pertama, menampilkan penelitian mengenai perkembangan perbankan syariah di Indonesia dalam konteks kekinian dengan data terbaru. Kedua, jika dibandingkan dengan beberapa penelitian terdahulu, kebanyakan dari penelitian terdahulu melihat faktor yang mempengaruhi tingkat profitabilitas perbankan syariah hanya dari variabel-variabel yang ada di dalam sistem perbankan itu sendiri. Dalam penelitian ini mencoba mengaitkan dengan salah satu faktor di luar sistem perbankan atau variabel makro ekonomi yaitu berupa infalsi.

CAR merupakan rasio kinerja perbankan yang berfungsi untuk mengukur kecukupan modal yang dimiliki oleh bank guna menunjang aktiva yang berpotensi terpapar risiko seperti jumlah kredit yang disalurkan oleh perbankan (Sudarmawanti dan Pramono, 2017). Dalam penjelasan yang lebih sederhana lagi, CAR dapat diartikan sebagai rasio modal yang harus dimiliki oleh perbankan terhadap kredit yang disalurkan oleh perbankan. CAR menjadi salah satu variabel yang digunakan dalam mengukur tingkat kesehatan perbankan. Jika nilai CAR yang dimiliki oleh suatu perbankan tinggi, maka bank tersebut sedang dalam keadaan baik, begitu juga sebaliknya. Tingginya angka CAR di suatu perbankan juga menandakan keuntungan bank yang semakin besar sekaligus menunjukkan bahwa perbankan tersebut dalam kondisi sehat.

CAR juga berkaitan dengan kredit yang disalurkan oleh perbankan kepada nasabah. Dalam menyalurkan kredit, bank membutuhkan modal atau dana. Sumber modal yang didapat oleh perbankan berasah dari sejumlah pihak seperi pemilik bank atau pemegang saham, pemerintah, bank sentral, para investor baik yang berasal dari luar negeri maupun dalam negeri. Selain digunakan untuk menyalurkan kredit, bank juga dapat menggunakan dana tersebut untuk mencari keuntungan seperti melakukan pinjaman antar bank (interbank call money) yang berjangka satu hari hingga satu minggu. (Fajari dan Sunarta, 2017).

NPF (Non Performing Financing) atau NPL (Non Performing Loan) merupakan kredit bermasalah yang disalurkan oleh pihak perbankan kepada penerima kredit dengan klasifikasi kurang lancar, diragunakan 
dan macet (Kamus Bank Indonesia, 2018). Istilah NPL ditujukan kepada perbankan konvensional sedangkan NPF ditujukan pada perbankan syariah. Rasio NPF menunjukkan kinerja perbankan syariah dalam mengatur risiko pembiayaan yang dilakukan. Semakin tinggi rasio NPF berarti bahwa kredit macet yang disalurkan semakin tinggi atau manajemen pembiayaan yang dilakukan bank buruk. Begitu sebaliknya, semakin rendah rasio NPF maka kinerja bank semakin baik dalam hal pengelolaan manajemen pembiayaan. (Sumarlin, 2016).

FDR merupakan rasio jumlah modal yang disalurkan oleh perbankan terhadap modal yang dimiliki oleh perbankan (Sumarlin, 2016). Dengan kata lain, FDR menunjukkan kemampuan perbankan dalam menyalurkan dana kepada debitur sekaligus membayarkan kembali kepada deposan dengan mengandalkan kredit yang disalurkan sebagai sumber likuiditas. (Sumarlin, 2016).

Inflasi adalah suatu keadaan di mana harga-harga akan suatu barang mengalami kenaikan dalam kurun waktu tertentu dalam suatu wilayah perekonomian (Sumarlin, 2016). Kenaikan herga-harga dalam inflasi terjadi dari periode ke periode selanjutnya dan angka kenaikan tersebut berbeda antara wilayah satu dengan lainnya. Kenaikan harga barang dalam inflasi terjadi pada semua barang yang telah ditentukan, bukan hanya terjadi pada satu atau dua barang saja. Jadi, jika kenaikan hanya terjadi pada satu atau dua barang saja maka tidak disebut inflasi (Sukirno, 2012). Dampak dari inflasi tidak hanya pada sektor riil saja, melainkan juga pada sektor keuangan (Ali, Mamoor, Yaacob, Gill: 2018).

Profitabilitas perbankan dalam penelitian ini mengacu pada ROA (Return On Asset). Dalam menentukan kinerja atau kesehatan perbankan, Bank Indonesia (BI) lebih merujuk ROA dari pada ROE (Return On Equity). BI lebih mengutamakan profitabilitas suatu bank yang diukur dengan aset yang dananya sebagian besar berasal dari dana simpanan masyarakat sehingga ROA dinilai lebih mewakili dalam pengukuran profitabilitas perbankan. (Avrita dan Pangestuti, 2016).

\section{METODE PENELITIAN}

Penelitian ini merupakan jenis penelitian deskriptif kuantitatif, yaitu mendeskripsikan dan menjelaskan pengaruh variabel independen terhadap variabel dependen. Variabel independen dalam penelitian ini meliputi CAR, NPF, FDR dan inflasi. Sedangkan variabel dependennya adalah tingkat profitabilitas perbankan syariah atau ROA.

Ruang lingkup penelitian meliputi seluruah populasi variabel yang akan diteliti yaitu CAR, NPF, FDR, inflasi dan ROA. Data yang digunakan merupakan data sekunder yang bersumber dari lembaga terkait yang menyediakan data. Untuk data CAR, NPF, FDR dan ROA diambil dari laporan bulanan statistik perbankan syariah yang dipublikasikan di laman resmi (website) Otoritas Jasa Keuangan (OJK). Sedangkan untuk data 
inflasi diambil dari laman resmi (website) Bank Indonesia (BI).

Periode penelitian dalam penelitian ini adalah mulai pada periode Juli 2015 sampai Agustus 2018 (38 bulan). Data digunakan disesuaikan dengan rentan waktu penelitian dari masing-masing variabel yang digunakan. Jika dilihat dari waktu pengumpulannya, maka jenis data dalam penelitian ini merupakan data time series (data urutan waktu) dalam bulanan.

Pemilihan sampel dalam penelitian menggunakan metode purposive sampling. Metode ini dipilih berdasarkan pada karakteristik tertentu sesuai dengan tujuan penelitian. Sehingga variabel yang digunakan adalah variabel yang sesuai dengan tujuan dari penelitian. Variabel yang tidak sesuai dengan tujuan penelitian tidak digunakan (Welta dan Lemiyana, 2017).

Definisi oprasional variabel dalam penelitian ini adalah sebagai berikut:

a. CAR (Capital Adiquacy Ratio), merupakan rasio yang digunakan untuk menghitung kecukupan modal suatu bank.

b. NPF (Non Performing Financing), merupakan rasio yang digunakan untuk mengetahui pembiayaan bermasalah yang ditanggung oleh perbankan berdasarkan total pembiayaan yang telah disalurkan perbankan.

c. FDR (Financing to Deposit Ratio), merupakan rasio yang digunakan untuk mengetahui seberapa besar pembiayaan yang disalurkan perbankan terhadap dana pihak ketiga yang dihimpun oleh perbankan.

d. Inflasi, merupakan suatu proses peningkatan harga-harga bahan kebutuhan pokok dari satu periode waktu ke periode selanjutnya di suatu wilayah perekonomian.

e. ROA (Return On Asset), marupakan rasio yang digunakan perbankan untuk mengetahui kemampuan manajemen perbankan dalam memperoleh laba. Dengan kata lain, ROA merupakan rasio yang digunakan untuk mengetahui tingkat profitabilitas perbankan. (Widyaningrum dan Septiarini, 2015).

Teknis analisis dalam penelitian ini menggunakan teknik analisis regresi linier berganda. Adapun beberapa langkah yang harus dilakukan dalam teknik analisis regresi linier berganda sebelum persamaan model regresi terbentuk adalah melakukan uji asumsi klasik meliputi uji normalitas data, uji autokorelasi, uji multikolinieritas, dan uji heteroskedastisitas.

Setelah seluruh uji asumsi klasik terpenuhi, langkah selanjutnya menentukan koefisien determinasi $\left(R^{2}\right)$ dan uji pengembangan hipotesis yakni uji $F$ dan uji t. Uji F digunakan untuk menguji pengaruh variabel independen terhadap variabel dependen secara simultas. Sedangkan

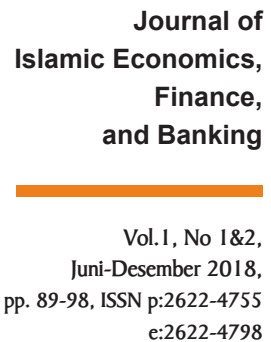

e:2622-4798 
uji t digunakan untuk menguji pengaruh variabel independen terhadap variabel dependen secara parsial (Widyaningrum dan Septiarini, 2015). IHTIFAZ - JIEFB Data yang digunakan dalam penelitian diolah dengan menggunakan bantuan perangkat lunak (software) EVIEWS versi 9. Adapun formula dalam pengujian data regresi linier berganda adalah sebagai berikut (Widarjono, 2013):

$$
Y=\beta_{0}+\beta_{1}+\beta_{2} X_{2 t}+\beta_{3} X_{3 t}+\beta_{4} X_{4 t}+e_{t}
$$

\section{Keterangan:}

$$
\begin{aligned}
& \mathrm{Y}=\mathrm{ROA} \text { (Return On Asset) } \\
& \mathrm{X}_{1}=\mathrm{CAR} \text { (Capital Adequacy Ratio) } \\
& \mathrm{X}_{2}=\mathrm{NPF} \text { (Non Performing Financing) } \\
& \mathrm{X}_{3}=\text { FDR (Financing to Deposit Ratio) } \\
& \mathrm{X}_{4}=\text { Inflasi. }
\end{aligned}
$$

\section{HASIL DAN PEMBAHASAN}

\section{Uji Asumsi Klasik}

Sebelum memasuki pembahasan mengenai uji pengaruh variabel independen terhadap variabel dependen dalam analisis regresi linier berganda, ada tahapan awal yang harus dilakukan. Tahapan awal tersebut yaitu uji asumsi klasik. Uji asumsi klasik meliputi beberapa tahapan diantaranya uji normalitas, uji heteroskedastisitas, uji multikolinearitas dan uji autokorelasi pada data penelitian. Hasil dari asumsi klasik menyatakan bahwa data penelitian lulus pada tahap uji asumsi klasik.

\section{Hasil Uji Hipotesis}

Data yang diolah merupakan data dari variabel perubahan. Adapun hasil dari pengolahan data adalah sebagai berikut:

Tabel 1. Hasil uji Hipotesis

\begin{tabular}{cllr}
\hline Uji Koefisien Determinasi $\left(\mathrm{R}^{2}\right)$ & Uji F & \multicolumn{2}{c}{ Uji t } \\
\hline \multirow{2}{*}{0.445286} & & CAR & 0.7065 \\
& \multirow{2}{*}{0.000085} & NPF & 0.0293 \\
& & FDR & 0.1746 \\
& & INFLASI & 0.3654 \\
\hline
\end{tabular}

Sumber: Output Eviews Versi 9.

Berdasarkan data penelitian yang telah diolah sebagaimana yang tersaji di atas dapat diketahui nilai koefisien determinasi $\left(R^{2}\right)$, nilai uji $F$ dan nilai uji t. Nilai koefisien determinasi $\left(R^{2}\right)$ pada intinya menunjukkan seberapa besar kemampuan model dalam menjelaskan variabel dependen (Khasanah, 2017). Dalam penelitian ini, nilai koefisien 
determinasi $\left(R^{2}\right)$ sebesar 0.445286 atau 44,52 persen, yang berarti bahwa variabel independen yang digunakan dalam model memiliki kemampuan menjelaskan variabel dependen sebesar 44,52 persen. Sedangkan sisanya sebesar 55,48 persen dijelaskan oleh variabel lain di luar model.

Uji F menunjukkan bahwa seberapa besar variabel bebas atau variabel independen secara simultas mempengaruhi variabel terikat atau variabel dependen (Khasanah, 2017). Uji F bertujuan untuk menentukan signifikansi pengaruh variabel independen secara bersama-sama terhadap variabel dependen. Tingkat signifikasi uji $\mathrm{F}$ dalam penelitian ini adalah 0,05 atau lima persen. Apabila nilai signifikansi uji $F$ di bawah lima persen, berarti variabel independen secara simultan berpengaruh terhadap dependen.

Nilai uji $\mathrm{F}$ pada penelitian ini sebesar 0.000085 yang mana nilai tersebut berada di bawah 0,05 (lima persen). Dengan kata lain, variabel independen meliputi CAR, NPF, FDR dan inflasi secara simultan mempunyai pengaruh dan signifikan terhadap variabel dependen berupa ROA.

Uji t dilakukan bertujuan untuk melihat seberapa besar pengaruh variabel independen secara parsial (individu) mempengaruhi variabel dependen (Khasanah, 2017). Dalam penelitian ini, penjelesan lebih lanjut mengenai nilai hasil uji t adalah sebagai berikut:

a. Pengaruh CAR terhadap ROA

Berdasarkan tabel hasil oleh data sebagaimana yang telah ditampilkan di atas, nilai probabilitas CAR sebesar 0.7065 yang mana angka tersebut lebih besar dari nilai alpha 0,05 (lima persen). Maka, dapat disimpulkan bahwa variabel CAR secara parsial tidak berpengaruh terhadap variabel ROA.

b. Pengaruh NPF terhadap ROA

Berdasarkan tabel hasil olah data di atas, nilai probabilitas NPF sebesar 0.0293 yang mana angka tersebut lebih kecil dari nilai alpha sebesar 0,05 (lima persen). Hal ini menunjukkan bahwa variabel NPF secara parsial berpengaruh positif dan signifikan terhadap ROA.

c. Pengaruh FDR terhadap ROA

Nilai probabilitas variabel FDR dalam penelitian ini sebesar 0.1746 yang mana angka tersebut lebih besar dari nilai alpha sebesar 0,05 (lima persen). Dengan kata lain, variabel FDR secara parsial tidak berpengaruh terhadap variabel ROA.

d. Pengaruh inflasi terhadap ROA

Variabel inflasi mempunyai nilai probabilitas sebesar 0.3654. Angka tersebut lebih besar dari nilai alpha 0,05 yang berati bahwa variabel inflasi tidak mempunyai pengaruh terhadap variabel ROA. 


\section{PEMBAHASAN}

Berdasarkan uji asumsi klasik yang telah dilakukan menunjukkan IHTIFAZ - JIEFB bahwa tidak ada masalah dalam pengolahan data. Sedangkan berdasarkan uji koefisien determinasi $\left(R^{2}\right)$ menghasilkan nilai sebesar 0.445286 . Ini berarti bahwa sebesar 44,52 persen variabel independen yang digunakan dalam model mampu menjelaskan variabel dependen. Sementara sisanya sebesar 55,48 persen dijelaskan oleh variabel lain. Variabel lain tersebut dapat berupa BOPO (biaya operasional pendapatan operasional) atau variabel makro ekonomi lainnya seperti pertumbuhan ekonomi, nilai tukar mata uang dalam negeri terhadap mata uang luar negeri dan jumlah uang beredar.

Secara simultan variabel independen CAR, NPF, FDR dan inflasi berpengaruh terhadap variabel dependen ROA. Hal ini menunjukkan bahwa perbankan syariah di Indonesia harus memperhatikan variabel CAR, NPF, FDR dan inflasi dalam melakukan perbaikan kinerja keuangan perbankan sekaligus dalam perolehan profitabilitas. Sebab tingkat profitabilitas perbankan syariah dipengaruhi variabel-variabel tersebut secara simultan. Dengan demikian, setiap perbankan harus menunjukkan kinerja keuangan yang baik guna memperoleh profitabilitas yang lebih tinggi. Temuan ini sejalan dengan temuan penelitian yang dilakukan oleh Widyaningrum dan Septiarini (2015) dan khasanah (2017).

Sedangkan secara persial, variabel variabel NPF berpengaruh positif dan signifikan terhadap ROA. Sementara variabel CAR, FDR dan inflasi tidak berpengaruh terhadap ROA. Ada beberapa penjelasan dari masingmasing variabel mengapa ada yang segnifikan dan ada yang tidak.

CAR tidak berpengaruh signifikan pada periode penelitian dapat disebabkan oleh sikap dari manajemen perbankan yang menjaga agar tingkat CAR pada perbankan syariah tetap sesuai dengan ketaatan yang ditentukan oleh bank sentral (BI) . Hal ini menyebabkan perbankan syariah tidak secara optimal memanfaatkan modal yang dimiliki (Widyaningrum dan Septiarini, 2015). Temuan ini sejalan dengan penelitian yang dilakukan oleh Almunawwaroh dan Marliana (2018).

NPF berpengaruh positif terhadap ROA. NPF merupakan rasio gagal bayar dalam penyaluran kredit. Sehingga semakin tinggi nilai NPF akan berakibat buruk pada perbankan. Begitu sebaliknya, semakin rendah nilai NPF akan semakin baik bagi kinerja perbankan. Hasil positif ini menunjukkan bahwa kinerja perbankan syariah baik dalam NPF. Dengan kata lain, tingkat gagal bayar yang disalurkan oleh perbankan syariah rendah yaitu sebesar 4,08 persen (Almunawwaroh dan Marliana, 2018). Temuan ini sejalan dengan temuan yang dilakukan oleh Almunawwaroh dan Marliana (2018) dan bersebrangan dengan temuan Khasanah (2017) dan Ananda (2012).

FDR tidak berpengaruh signifikan terhadap ROA dalam hasil penelitian ini. Hal ini disebabkan pembiayaan yang disalurkan oleh pihak perbankan syariah belum berjalan dengan efektif dan optimal. Sehingga 
menyebabkan pembiayaan yang tidak lancar meningkat seiring dengan total pembiayaan yang dilakukan oleh pihak perbankan (Widyaningrum dan Septiarini, 2015). Temuan ini sejalan dengan temuan dalam penelitian Khasanah (2017).

Inflasi tidak berpengaruh terhadap tingkat profitabilitas perbankan syariah (ROA) di Indonesia selama periode penelitian. Hal ini menunjukkan bahwa meskipun inflasi mengalami kenaikan, tidak menurunkan tingkat profitabilitas yang dimiliki oleh perbankan syariah. Begitu juga sebaliknya, misalnya inflasi mengalami penurunan tidak menjadi penyebab naiknya tingkat profitabilitas perbankan syariah di Indonesia selama periode penelitian. Temuan ini mendukung hasil penelitian yang dilakukan oleh Welta dan Lemiyana (2017) dan Sumarlin (2016).

\section{KESIMPULAN}

Berdasarkan hasil uji asumsi klasik menyatakan bahwa tidak ada masalah dengan data yang digunakan dalam penelitian. Kemudian berdasarkan hasil uji koefisien determinasi $\left(R^{2}\right)$ menghasilkan nilai 0.445286 atau 44,52 persen, yang berarti bahwa variabel independen yang digunakan dalam model memiliki kemampuan menjelaskan variabel dependen sebesar 44,52 persen. Selanjutnya uji $F$, pada penelitian ini menghasilkan nilai sebesar 0.000085 yang mana nilai tersebut berada di bawah 0,05 (lima persen). Dengan kata lain, variabel independen meliputi CAR, NPF, FDR dan inflasi secara simultan mempunyai pengaruh signifikan terhadap variabel dependen berupa ROA. Sedangkan secara persial, berdasarkan uji t, variabel NPF berpengaruh positif dan signifikan terhadap ROA. Sementara variabel CAR, FDR dan inflasi tidak berpengaruh terhadap ROA.

\section{REFERENSI}

Ali Q, Mamoor S, Yaacob H, Gill MUT. (2018). Impact of macroeconomic variables on Islamic banks profitability. Journal of Accounting and Applied Business Research, 1(2): 1-16.

Almunawwaroh M, Marliana R. (2018). Pengaruh CAR, NPF dan FDR terhadap profitabilitas bank syariah di Indonesia. Amwaluna, 2(1): 1-17.

Anada MA. (2013). Analisis pengaruh CAR, FDR, NPF dan BOPO terhadap $R O A$ bank umum syariah (studi kasus pada bank umum syariah di Indonesia periode 2010-2012). UIN Sumatra Utara.

Ariyani, D. (2010). Analisis Pengaruh CAR, FDR, BOPO dan NPF terhadap profitabilitas pada PT Bank Muamalat Indonesia TBK. Al-Iqtishad, II(1): 97-124.

Avrita RD, Pangestu IRD. (2016). Analisis pengaruh CAR, NPL, LDR, NIM, dan BOPO terhadap profitabilitas bank (perbandingan bank 
IHTIFAZ - JIEFB

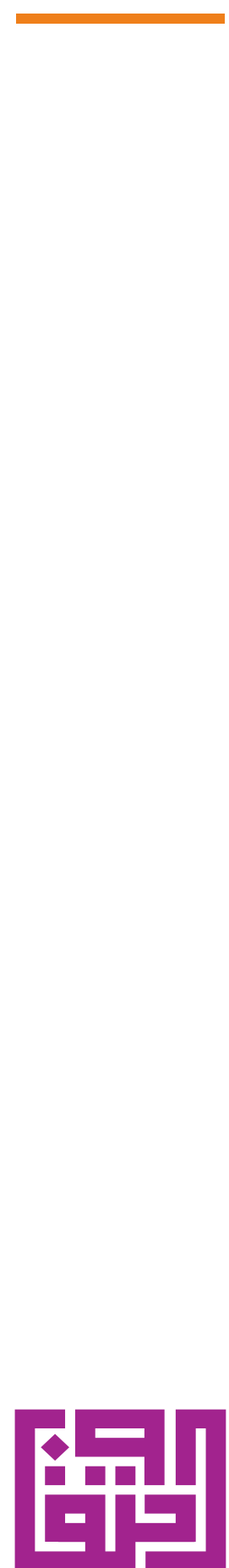

IHTIFAZ

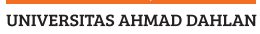

Kampus 4

Universitas Ahmad Dahlan Jl. Ringroad Selatan, Tamanan Banguntapan, Bantu Yogyakarta 5519 umum go public dan bank umum non go public di Indonesia periode tahun 2011-2014). Diponegoro Journal of Management, (5)2: 1-13.

Bank Indonesia. Data Laporan Inflasi. [cited: 2018 Oct 29]. . Istilah NPF dan NPL. [cited: 2018 Nov 1]. Available from: https://www.bi.go.id/id/Kamus.aspx.

Bank Muamalat Indonesia. Laporan Tahunan 2016. [cited: 2018 Oct 31].

Diknawati DA. (2014). Analisis pengaruh CAR, NPF, FDR, dan BOPO terhadap profitabilitas bank umum syariah. STIE Perbanas.

Fajari S, Sunarto. (2017). Pengaruh CAR, LDR, NPL, BOPO terhadap profitabilitas bank (studi kasus perusahaan perbankan yang tercatat di Bursa Efek Indonesia periode tahun 2011 sampai 2015). Prosiding Seminar Nasional Multi Disiplin Ilmu \&Call For Papers Unisbank Ke-3 (Sendi_U 3). Unisbank, P. 853-862.

Khasanah U. (2017). Pengaruh CAR, NPF, BOPO, FDR dan inflasi terhadap return on asset (ROA) pada bank umum syariah di Indonesia periode 2012-2016. IAIN Salatiga.

Otoritas Jasa Keuangan. Laporan Statistik Perbankan Syariah: Data CAR, NPF, FDR dan ROA. [cited: 2018 Oct 31].

Perdanasari PY. (2017). Analisis pengaruh CAR, NPF, FDR, BOPO, BI $R A T E$ dan inflasi terhadap tingkat profitabilitas perbankan syariah di Indonesia periode 2011-2017. Universitas Islam Indonesia.

Sari MD, Bahari Z, Hamat Z. (2013). Perkembangan perbankan syariah di Indonesia: suatu tinjauan. Jurnal Aplikasi Bisnis, 3(2): 120-138.

Sudarmawanti E, Pramono J. (2017).Pengaruh CAR, NPL, BOPO, NIM dan LDR terhadap ROA: studi kasus pada Bank Perkreditan Rakyat di Salatiga yang terdaftar di Otoritas Jasa Keuangan tahun 20112015. Among Makarti, 10(19): 1-18.

Sukirno S. (2012). Makroekonomi Teori Pengantar. Jakarta: Rajagrafindo.

Sumarlin. (2016). Analisis pengaruh inflasi, CAR, FDR, BOPO, dan NPF terhadap profitabilitas perbankan syariah. ASSETS, 6(2): 296-313.

Syachfuddin LA, Rosyidi S. (2017). Pengaruh faktor makroekonomi, dana pihak ketiga dan pangsa pembiayaan terhadap profitabilitas industri perbankan syariah di Indonesia tahun 2011-2015. Jurnal Ekonomi Syariah Teori dan Terapan, 4(12): 977-993.

Welta F, Lemiyana. (2017). Pengaruh CAR, inflasi, nilai tukar terhadap profitabilitas pada bank umum syariah. I-Finance, 1(1): 85-100.

Widarjono A. (2013). Ekonometrika: pengantar dan aplikasinya disertai panduan eviews. Edisi Keempat. Yogyakarta: UPP STIM YKPN, 1-378.

Widyaningrum L, Septiarini DF. (2015). Pengaruh CAR, NPF, FDR, dan OER terhadap ROA pada bank pembiayaan rakyat syariah di Indonesia periode januari 2009 hingga Mei 2014. JESTT, 2(12): 970-985. 